\title{
Skimming the Profit Pool: The American Mutual Fund Scandals and the Risk for Japan
}

\author{
Andrew Peterson
}

Received: 24 April 2010 / Accepted: 10 May 2010/

Published online: 8 June 2010

(C) The Author(s) 2010. This article is published with open access at Springerlink.com

\begin{abstract}
This paper examines conditions and structures that led to abuses in the American mutual fund industry. The scandals unfolded in 2003 when a whistleblower alerted authorities to illegal and unethical trading practices between institutional investors and mutual fund companies. The abuses included late trading, market timing, illegal sales practices, and excessive fees, with damages estimated at well over US \$4 billion per year. While this scandal involved American companies, there are indications that other countries could be at risk of similar wrongdoing. Archival data are used to understand the regulatory conditions that allowed for illegal practices to proliferate throughout the American mutual fund industry. These conditions are compared to those in Japan to assess the potential for similar abuses and how they might best be prevented.
\end{abstract}

Keywords Japan $\cdot$ Mutual fund scandal $\cdot$ Investment trust $\cdot$ Deregulation

The mutual fund industry is a popular destination for many Americans' retirement savings. Within the past decade, it was embroiled in a widespread scandal that involved the industry's most recognizable names and that resulted in over US \$4 billion in fines. This paper examines how increased competition among firms, lack of transparency in financial transactions, conflicts of interest in mutual fund governance, and traditions of commerce created a crime-facilitative environment (Needleman and Needleman 1979) in the mutual fund industry that resulted in the scandal. While the offenses involved American companies, foreign financial markets have comparable institutional structures, making them easily susceptible to similar abuses. In order to understand the risk to foreign markets, the concept of a mutual fund and its purpose will be explained, followed by a discussion of the scandal's crime-facilitative structures to see how they allowed and encouraged trading abuses in the industry. Finally, the paper will consider these issues in the context of Japan, a country with one of the world's largest mutual fund industries, in order to assess the potential for a similar scandal to occur there.

\footnotetext{
A. Peterson $(\square)$

School of Social Ecology, University of California, 5300 Social and Behavioral Sciences Gateway, Irvine, CA 92697-7050, USA

e-mail: apeterso@uci.edu
} 


\section{Mutual Funds: An Overview}

A mutual fund is a financial instrument comprised of a collection of stocks, bonds, or other investments. Mutual funds are priced at the end of each trading day, rather than in real time, as each individual fund investment can vary second-by-second, causing the mutual fund price to change a great deal from one moment to the next. At the close of the market, when securities have stopped trading, the fund's price is calculated using closing prices from individual securities that comprise the portfolio. The closing prices are combined and averaged according to each security's ratio to the overall fund portfolio. The net mutual fund purchases or sales are also figured into the fund's value, which is divided by the number of outstanding shares to determine the fund's price. This price is typically set just after 4:00 p.m. Eastern Standard Time (Potts 1972).

The etiology of mutual funds has been as a long-term "buy and hold" investment. Shortterm investments in mutual funds hurt long-term investors because they skim profits from the fund. When a mutual fund manager invests, he or she places percentages of investors' assets in different securities and a certain amount is kept in cash. The amount of cash retained in a fund eliminates the risk of losing the whole portfolio's value due to market volatility. Cash can also be used to pay investors who sell their shares. When investors rapidly trade in and out of a fund, more cash is withdrawn to pay them. Also, the increased number of transactions can force the mutual fund to have to buy or sell stocks to accommodate its varying pool of money. Each transaction creates commissions that the fund must pay. These costs either come directly out of the fund's profits or they are passed along to the investor in the form of fees (Wall Street Journal 1999). In addition, these conditions may force a fund manager to make transactions at a loss on their investment, further hurting the fund's potential performance.

\section{The Mutual Fund Industry in the US}

The first modern mutual fund appeared in 1924 when the Massachusetts Investment Trust created a fund open to outside investors. The fund started with approximately two hundred investors and US \$50,000 in assets (Bogle 2005). After the 1929 stock market crash and the Great Depression, the securities industry underwent numerous changes, including creation of the Securities and Exchange Commission (SEC) to oversee the industry. The Investment Company Act of 1940 regulated the mutual fund industry by requiring all funds to register with the SEC and meet standards of operation, disclosure, and securities transactions, which had been absent until this period (Russell 2007). The Investment Company Act of 1940 did not alter the old method of pricing mutual funds. Under the Act, "backward pricing," which allowed investors to make trades at the previous day's price was still employed. This pricing loophole was corrected in 1968 when Rule 22c-1 was adopted by the SEC, making forward pricing the standard (Sterngold 1994). Forward pricing requires that mutual fund trades be conducted in the next calculated price.

In 2003, former SEC commissioner Harvey Goldschmidt stated, "The mutual fund industry has been blessed - and blessed is the only word - by being relatively free of scandal" (Bogle 2005). That statement that had been true since the Investment Company Act was passed almost 70 years earlier. By the end of 2003, endemic late trading and market timing for preferred clients sullied the industry's former clean record. Those involved in the scandals reads like a who's who of American finance: Bank of America, Bank One, Deutsche Bank, Bear Sterns, Merrill Lynch, Smith Barney, Charles Schwab, 
Janus, Fidelity, Putnam, and Strong Funds, all of whom had engaged in some degree of illegal mutual fund trading.

\section{Scandal Among US Mutual Funds}

In October of 2002, Noreen Harrington, a former executive with the investment arm of the Stern family fortune, which included Canary Capital Partners hedge fund, contacted the New York Attorney General's office. She had overheard brokers bragging that the hedge fund was illegally trading their mutual fund investments. By the summer of 2003, the Attorney General's office had issued subpoenas for Canary Capital Partners, and Attorney General Eliot Spitzer began a broader investigation into the mutual fund industry. $\mathrm{He}$ discovered that various hedge funds had been market timing and late trading with the assistance of brokerage firms that placed the mutual fund orders and third party firms that processed the orders (see Appendix 1) (Elkind 2004).

Cooperation from former employees buttressed the case against Canary Capital Partners. Canary's owner, Eddie Stern, quickly reached a settlement with Spitzer's office and became their star witness, pinpointing different players involved in the scandal (Elkind 2004). As news of the investigation became public, the media began to discuss a scandal in the former "scandal-free" industry.

The National Association of Securities Dealers (NASD) and the SEC launched their own investigation into the mutual fund industry, joining forces with Spitzer and other state Attorney Generals. The joint investigation led to ten criminal convictions, over 60 settlements, mutual fund executives and traders being fired and banned from the securities industry, rule changes from the regulatory agencies, and more than US \$4 billion in fines.

\section{Late Trading and Market Timing}

The integrity of the forward pricing system is supposed to be guaranteed by time-stamping tickets as orders are received at brokerage firms. Orders are then passed along to a third party to be processed. The backlog of orders results in many trades placed before the 4:00 p.m. deadline being completed hours later. The system is violated when certain customers are allowed to place orders after the market closes, buying or selling their mutual funds at an already determined price. The other manner of late trading involves a brokerage firm colluding with certain privileged investors to place legitimate mutual fund orders when information that is expected to affect the mutual fund's price will be released after the market's close. The order is processed only if the information would benefit the investor. If the investor would not benefit, the order is canceled (see Appendix 1). Spitzer characterized these practices as "betting on a horse race after the horses have crossed the finish line" (Media Center 2003). The practice is similar to insider trading in that it eliminates investment risk, victimizes investors through preferential treatment given to a privileged few, and destroys integrity and trust in the financial markets.

The practice of late trading has been outlawed by the Martin Act-a New York State securities law enacted in 1921 and commonly used to prosecute bogus stock sales and boiler room establishments - and by the Federal Investment Act of 1940 (McTamaney 2003). Late trading is unique to mutual funds because they are priced only at the close of the market and have this forward pricing policy that requires that orders be processed after the market has already closed. 
Despite its prohibition, a study of late trading discovered that the practice was prevalent in the industry. A sample found evidence of late trading in 39 of 66 mutual fund families. Based upon late trading levels in the sample, it is estimated that late trading costs other investors approximately US \$400 million per year (Zitzewitz 2006).

Late trading alone does not guarantee a profit for investors. They ensure a profit only if the investor ${ }^{1}$ is able to make a late purchase after hearing good news about a company or sector and then sell the mutual fund the next day. This way they make their purchase at a price that does not include the good news and sell the fund after the good news adds to its price. This type of rapid in-out trading often associated with late trading is known as market timing ${ }^{2}$.

While the SEC does not expressly outlaw market timing in mutual funds, it is considered unethical because of its negative effects on long-term investors. In addition, each mutual fund prospectus states that the fund does not allow market timing. By allowing it, a fund is misrepresenting its position on the issue and defrauding its customers by contradicting statements from the prospectus. Therefore, the offense lies not in allowing market timing, but in lying to their customers through the prospectus.

Funds also have created disincentives to market timing through fees or bans for shortterm investors. In this scandal, certain customers were exempted from these penalties and the fund company explicitly or implicitly condoned their market timing by agreeing to allow the activity or by not pursuing those blatantly breaking the rules. In fact, David Brown of the New York Attorney General's office discovered form-letter contracts between mutual fund companies and market timers (Sterngold 1994). This represents another case of disconnect between the organizations' stated rules and their practices as well as preferential treatment afforded investors of a certain status.

Estimates suggest that market timers have cost long-term investors over US \$4 billion per year since 1998-1999, the year when market timing was most popular (Zitzewitz 2003). Some fund companies began to crack down on market timers. Recovered emails from the case against Prudential show that some mutual fund companies had tried to stop all trading by Prudential's market timing brokers (Thomas 2006). Other mutual funds had asked brokerage firms and traders to cease and desist market timing in their funds. In response, traders attempted to disguise the practice by changing account names and splitting large trades into several smaller ones to avoid detection.

The motivation for mutual fund companies to allow late trading and market timing is based in their compensation scheme. A mutual fund manager is paid a percentage of the total assets invested in the fund. The theory behind this practice is similar to free market theories in that the best performing funds will attract the most money, rewarding these managers for their high returns. In this case, hedge funds and other institutional investors subverted the spirit of the incentive by investing large amounts in the mutual fund-maybe tens of millions of dollars - with the understanding that this investment would be long term and would allow the fund manager to substantially increase his or her "assets under management." In exchange for the large investment, the mutual fund manager would allow the investor to use a smaller account, perhaps one to five million dollars, to late trade and

\footnotetext{
${ }^{1}$ In this case, "investor" can mean lay persons investing their own money, or the broker investing on behalf of clients.

${ }^{2}$ Market timing is an investment strategy that attempts to capitalize on short-term price fluctuations and is not always associated with late trading. It may be utilized with various types of securities and may be both legal and ethical depending upon the type of security that is traded.
} 
market time (Elkind 2004). This way, both parties benefit, while average investors lose by realizing reduced profits or increased losses from their investment.

Investors do not necessarily need to collude with a mutual fund to engage in market timing and many market timers practiced their strategy in spite of the fund's best efforts to prevent illegal trades. The problem with prevention comes because market timers are detected only after they have already made a number of trades. This issue is compounded because of difficulties in monitoring a large number of accounts and the lack of transparency in mutual fund transactions (Henriques 2004). Because each mutual fund company is exclusively responsible for detecting market timing and enforcing its stated policies, a fund faces a loss of business if it prevents an investor from market timing while another fund allows it. The investor may transfer assets to the second company. Allowing mutual funds to enforce their own market timing rules may give them flexibility to make exceptions based upon the circumstances of each case, but it also creates a conflict of interest which may create lax enforcement of these policies.

\section{Factors in the US Scandal}

\section{Rapid Growth of the Stock Market and Mutual Fund Industries}

In 1952 the New York Stock Exchange (NYSE) conducted its first census and found that almost 6.5 million Americans, or about 4\% of the population, owned common stock (Geisst 2000). At this time, the stock market had an average volume of 1.3 million shares traded daily. This represented a return of confidence in the markets for the first time since the Great Depression, and investment advice was occasionally found in newspapers and magazines. The NYSE then began a widespread educational campaign to increase public participation in the securities markets. By the end of the 1950s almost twice as many Americans owned stocks. In response to increased trading volume, the number of stock brokers and investment bankers doubled between 1950 and 1960 (Geisst 2004). By 1999, the census had almost 80 million Americans directly owning stock, and millions more invested through various retirement plans and mutual funds, representing almost $40 \%$ of the US adult population. The average trading volume had increased to over 800 million shares per day (Geisst 2000). In addition, investment advice became popular in the media. Currently, the Wall Street Journal, Barron's, and Business Week are well recognized titles among the dozens of daily, weekly, and monthly magazines and periodicals that focus on investments and investing advice. CNN, MSNBC, and the Bloomberg Network all represent cable news channels that include large chunks of programming dedicated to investor news.

When individual retirement accounts (IRAs) were developed in 1981, mutual funds benefited from persons seeking long-term investments with lower risks. Now, mutual funds are also commonly purchased in $401 \mathrm{k}$ and other employee retirement accounts. In 2003, mutual funds comprised almost a quarter, or approximately US $\$ 3$ trillion dollars of the American retirement asset market. Retirement accounts also accounted for $36.4 \%$ of mutual fund assets (Sterngold 1994). The popularity of IRAs and the use of mutual funds as a compatible investment vehicle greatly increased the amount of money invested in the industry.

When the Investment Company Act of 1940, the major legislation regulating mutual funds, was passed there were 68 mutual fund companies and approximately US \$450 million from almost 300,000 investors (Potts 1972). Now there is over US $\$ 7$ trillion 
invested in mutual funds. In 2003, 91 million individuals in 53 million households owned mutual funds. This represented almost half of the households in the United States, and is twice the percentage of households that owned mutual funds in 1990, and more than eight times the percentage that owned mutual funds in 1980 (Sterngold 1994).

While growth may not be an actual "structure," rapid growth in the mutual fund industry contributed to the scandal by giving offenders a larger pool of investments from which to skim. Without as many investors in mutual funds, the negative effects of market timers and late traders would have been more apparent and mutual funds would have performed worse, potentially drawing away more long-term investors and further magnifying the negative effect on the performance and reputation of the mutual fund industry.

\section{Transparency}

The lack of transparency between brokerage firms and mutual fund companies allowed market timing investors to hide their practices from the mutual funds. During the scandal, brokerage firms could hold clients' mutual fund investments in omnibus accounts. This made it difficult for mutual funds to determine exactly which customers were making trades and thus ferret out who was engaging in market timing. Anonymity allowed investors to conduct illegal trades without fear of detection. In the odd cases where market timing and late trading were detected and perpetrators identified, market timers were often able to use their broker to open up new accounts and break up large trades into multiple smaller trades that did not appear on fund companies' radars. This allowed the practices to continue unpunished, while mutual funds ineffectively chased offenders (Henriques 2004). The lack of transparency between the two organizations made collusion between brokers and investors a virtually unstoppable market timing and late trading force.

As an example of this collusion, the case against Prudential centered on four brokers in the company's New York offices who concocted an elaborate plan to execute up to a 1,000 trades a day for their hedge fund clients by disguising the origin of the trades. Regulators found more than 25,000 emails between 68 different mutual fund companies and Prudential over a 12-month period, asking that Prudential stop these abusive practices (Henriques 2003). The brokers from Prudential tried to avoid detection by creating new accounts from which to trade and splitting large trades into multiple smaller trades. In addition to a company fine, the SEC sued the four brokers involved. They now face several potential punishments including: fines, returns of any profits made from the abusive trades, and bans from the securities industry (Thomas 2006).

The SEC has attempted to address the lack of transparency through regulation. Part of the newly passed rule $22 \mathrm{c}-2$ allows mutual funds to obtain more information about investors' transactions. The rule also removed brokerage firms' ability to use omnibus accounts for mutual fund investments. It further required that brokerage firms provide information on which clients are making trades. The brokerage must also agree to follow the mutual fund's instructions to restrict or prohibit any shareholder's future purchases or exchanges if that shareholder violates the fund's market timing policies (NYSE 2008).

\section{Competitive Environment}

The competitiveness of the mutual fund industry also played a role in encouraging illegal behavior. This substantiates the findings of Wheeler and Rothman (1982) that competitive markets are more likely to engage in fraud-although they incorrectly predicted that perpetrators would be small and on the industry's fringe. The increase in investors has been 
coupled with an increase in mutual fund companies. Fund managers' successes and failures are tracked and displayed month to month. The successful mutual fund manager has even become a bit of a celebrity. They are regularly featured in newspapers, magazines, and on television shows. The "hot fund manager" may even be asked to share insights with the investing public. This change in the environment, plus the ability to make tremendous profits, lures fund managers to seek out institutional investors that can quickly boost a fund's "assets under management." The same is true, perhaps more so, for brokers who gain less fame, but receive more direct financial benefit from commissions when they gain new, wealthy clients. In this situation, institutional investors can have bargaining power and potentially can negotiate for the "best deal" (Elkind 2004). This creates an environment where a few large hedge funds and other major investors possess tremendous power while facing significantly less regulation than the mutual funds and brokers with whom they are doing business. In the recent scandals this resulted in collusion in conducting illegal trades.

This change in the investing environment is borne out in demographic studies of the stock market. In a 1960 New York Stock Exchange study, institutions and intermediaries were responsible for only $24 \%$ of total share volume and just $29 \%$ of the corresponding dollar value, with individual investors doing the most trading. During the first 6 months of 1969 , institutional customers had substantially increased their activity, accounting for $41 \%$ of the share volume and almost $46 \%$ of the dollar value. The individual investor's impact, on the other hand, declined from nearly $53 \%$ of the total share volume in 1960 to only $35 \%$ in 1969. By 1976 institutions and their intermediaries accounted for just fewer than $45 \%$ of the total shares traded on the NYSE. However, their proportion of the corresponding dollar value climbed to $55 \%$. Trading by NYSE member firms for their own accounts fell to $22 \%$ (NYSE 2008). Individuals increased their share proportion somewhat but maintained the same level in terms of dollar value.

On 1 May 1975 brokerage commissions were deregulated and the fixed rates that had existed since the stock market's beginning were eliminated (Geisst 2004). Liberalization brought about discount brokerage houses that are now commonplace in the United States. Discount brokerage houses offer less advice and stock research than full-service brokerage firms. With reduced services and no floor for commissions, discount brokerages can offer lower prices for conducting securities' transactions. More than 100 discount brokerage firms have a growing share of the US market. The largest discount broker, Charles Schwab, enjoyed a net revenue of US $\$ 4.3$ billion in 2006, which is approximately one-eighth of Merrill Lynch's net revenue over the same period. This occurred despite the fact that Merrill Lynch has been established for over 90 years, offers many more products and services, including lending and investment banking, and has almost five times as many employees as Charles Schwab (Charles Schwab 2006; Merrill Lynch 2006). The exact impact that discount brokerages have had on the industry may be difficult to measure, but the most obvious sign is that full-service brokers have begun to compete with the discount firms, offering on-line trading and reduced commissions for reduced services.

\section{Conflicts of Interest}

The lack of independence between a mutual fund's chair and its board of directors is a major structural factor in the proliferation of trading abuses. Several attempts have been made to address the issue through regulation (Damato and Burns 2004). A mutual fund company can sell different mutual funds, and many chairmen and board members of one fund manage other funds within the same company. This creates a conflict of interest between the board members' duty to protect shareholders' rights and their desire to make 
money for the company, not to mention the cronyism and quid pro quo agreements that may occur with the board of directors.

Critics of reform on this issue point out that mutual fund companies like Fidelity and T. Rowe Price, who did not have independent chairmen, were found not to have been part of the market timing and late trading scandals (Solomon and Hechinger 2004). In addition, some funds involved in the scandal, such as Putnam Investments, had independent chairmen. This position has been countered by outside research, "[F]unds that have lower expense ratios and more outside directors have responded more aggressively to the arbitrage issue, implying that fund governance is an important determinant in how and whether funds respond to the arbitrage issue (SEC 2007)". A senior mutual fund analyst for the financial publication Morningstar supported this finding, saying, "We can count on one hand the number of instances in which a fund's board has stood up to the adviser and said, in essence, 'You're fired' (Lutton 2007)." This seems to indicate that an independent chairperson and board of directors do not necessarily eliminate opportunities for fraud nor does the absence of an independent chair and board guarantee that fraud will occur. However, independent actors who have a responsibility to protect shareholders' interest may help reduce the likelihood that fraud occurs within the organization.

In addition to requiring an independent chairperson, the SEC has considered mandating that $75 \%$ of the directors of the board also be independent. Currently, the 1940 Securities Act requires that only $40 \%$ of the directors of the board be independent from the fundmanagement company (Damato and Burns 2004).

\section{Traditions of Commerce}

One of Needleman and Needleman's (1979) original findings was that "traditions of commerce" helped create a crime-facilitative environment in the securities industry. Traditions of commerce refer to industry-wide practices or policies that are used in the course of business despite being outdated. The practices and policies are embedded in the industry's history and competitive structure and continue despite the industry's ability to otherwise perform more efficiently (Needleman and Needleman 1979). In Needleman and Needleman's study of securities fraud, they found that paper certificates used to represent the customer's purchase but that their desire to have a "tangible asset" was inefficient and a waste of resources. The second tradition was the trust that bankers automatically gave to clients and other bankers without conducting the necessary background checks to verify information. This tradition allowed con men to use the bankers' trust against them to defraud their institutions.

Traditions of commerce may be especially relevant to mutual fund fraud, as once-a-day pricing and use of order tickets are archaic traditions that are no longer necessary in a modern system. These processes exist despite current technology which could eliminate many opportunities for late-trading. Order tickets and a time-stamping system are vulnerable to manipulation, as seen during the mutual fund scandal. Brokers who had access to the time stamping machine could manually tamper with it and backdate orders. Also, as previously mentioned, orders that do not benefit the investor can be discarded by colluding brokers. An electronic system that automatically sent orders to clearinghouses to be processed as well as a paper version of the order ticket as a back-up would solve several problems and improve efficiency in the current system. Once-a-day pricing is no longer necessary given computers that can instantly track prices regardless of market volatility and investment changes made by mutual fund managers. 


\title{
Japan's Commonalities with the US
}

\author{
Big Bang De-Regulation
}

America strongly influenced Japanese rebuilding after World War II. This influence carried over to Japanese financial regulation with the installation of American, post-Great Depression style regulations (Malcolm 2001). These regulations separated the functions of banking and securities firms, not allowing one company to perform both duties. The 1990s saw Japan begin to remove some of these rules ${ }^{3}$. In 1993 the Financial Systems Reform Act removed the barriers between banks and securities firms in order to promote competition (Hamao and Hoshi 2000).

In the late 1990s Japanese Prime Minister Hashimoto introduced the "Big Bang" initiative, which sought to reform and de-regulate six areas of the Japanese economy. This was adopted to boost the Japanese economy by bringing more business to the Tokyo securities market. Tokyo markets had lost favor with investors after Britain and the United States deregulated their financial industries, allowing the London and New York markets to offer advantages to investors through relaxed rules (Toya 2006).

The notion behind this type of mass de-regulation takes its inspiration from astrophysics as the "Big Bang" was a large, singular event that recreated the universe. In this case, deregulation of the financial markets was designed to recreate the Japanese "economic universe." However, this idea was not original. Great Britain passed the Financial Services Act of 1986, which also was referred to as the "Big Bang." This piece of legislation removed fixed commissions among London's securities market so that competition could lower commissions and, therefore, reduce prices for consumers. The goal of the legislation was to recapture business that had been lost to the NYSE after the United States had removed fixed commission rates in 1975. Ironically, removal of fixed commissions was never intended for average investors, but rather was aimed at institutional investors (Geisst 1993). Even at that time, institutional investors were prioritized over individual investors. The Japanese viewed the success of Britain's Big Bang deregulation and followed suit, making themselves more competitive in the international securities markets.

The idea that Big Bang deregulation could lead to a Japanese financial scandal is ironic because, in addition to the need to compete in international financial markets, widespread corruption and scandal in the financial sector was one of the reasons that Japan decided to reform the financial industry (Hall 1998). The number of scandals and the extent of damage done in Japan between 1980 and 1996 required changes to be made; however, reform only changes practices, it does not necessarily create a problem-free environment.

Part of Hashimoto's deregulatory plan affected the Japanese version of the mutual fund market, known as an investment trust. The reform included a liberalization of laws regarding who could sell these investments. The Japanese government previously required that any seller of investment trusts be licensed, and only brokers were allowed to apply for these licenses. In addition, there were restrictions on the ability of non-banks to conduct foreign business. After the Big Bang initiative, the license requirement was changed to a simple registration with an approval system that applied only for derivatives, underwriting, and other areas with higher risks (Hall 1998). Investment trust companies were able to sell directly and the Japanese had more avenues to invest in foreign markets (Toya 2006). In

\footnotetext{
${ }^{3}$ By that time the United States had also removed the post-Great Depression regulations. The Garn-St. Germain Act, for example, ended Great Depression era regulation of the Savings and Loan industry. The act was named as a contributing factor in the Savings and Loan crisis (Black 2004; Pontell 2004).
} 
2001, banks were permitted to sell investment trusts or lease office space to investment trust management companies that wanted to sell directly to the public. Securities companies were also able to engage in any area of securities-related activities that they wished (Hall 1998). This type of de-regulation increases competition for brokerage firms who must try to create relationships with investors who now have more options for investing. The brokerage firms also faced a reduced profit margin because Big Bang deregulation removed any price floors on brokerage commissions. While economic theory posits that increased competition is positive, William Black's work on control fraud indicates that such economic theories do not consider the increased likelihood of fraud being committed in these environments (Black 2005). As shown in the American mutual fund scandal, increased competition among sellers gave institutional buyers leverage to negotiate for the rights to trade illegally.

Big Bang de-regulation of the investment trust industry was designed to increase transparency and enhance their system of regulation, which is generally valuable to the investor. However, Japanese investment trusts have a poor history of transparency. In 1994, the New York Times noted that Japanese investment trusts do not indicate their investment philosophies, which securities they own, past performance, or the name of their fund manager (Sterngold 1994). This makes it difficult for investors to differentiate among investment trusts and reach an informed investment decision. Steps toward transparency in the financial sector can help the Japanese, but when investors do not have access to basic information, how can they trust their investment? This lack of information gives mutual funds the ability to abuse investors without their knowledge.

The lack of valid financial information also has been identified in other Japanese frauds such as the Seibu, Livedoor, and Kanebo cases. In the Seibu case, it was discovered that the company had falsified reports to the Tokyo Stock Exchange for the previous 50 years (The Japan Times 2004). The improvements listed within the Big Bang plan are likely to upgrade the previous system in terms of preventing fraud, but the rules regarding information disclosure, external audits, conflicts of interest, market manipulation, surveillance and enforcement, and mingling of funds are either vague in their calls for "improvement" or "broadening," or they are attempts to finally meet international standards (Hall 1998).

The liberalization of brokerage commissions in Japan has increased the opportunity for mutual fund abuse in two different manners. The direct effect is lower commissions and greater ability to conduct trades, since the act is less cost-prohibitive. This is especially relevant to traders, such as market timers, who conduct many trades over a short period of time. The indirect effect is increased competition from an influx of discount brokerage firms. Deregulating commission may increase the brokerage firms' desire to collaborate with investors as the firms seek to maintain profits in the face of increased competition.

In addition, banks have been granted the ability to sell their own investment trusts. Currently, all major banks have launched direct investment trust sales, with a minimum investment of 10 million yen. This increased access makes the investment trust available to the majority of the public and will likely increase their popularity as an investment vehicle (Malcolm 2001). This further enhances competition as more mutual funds compete for investors.

\section{Japanese Business Culture}

The Japanese business culture creates unique opportunities for white-collar criminals. In the United States, the mutual fund scandal, Enron, and other large corporate and financial frauds have been exposed by whistleblowers from inside the organizations. A major study by Hamilton and Sanders (1996) noted that the Japanese were significantly less likely than 
Americans to agree that a person "should not keep silent when you see a fellow employee do something seriously wrong at work." This strong adherence to conformist social mores and business hierarchies reduces the chance that a Japanese whistleblower will expose a scandal. As noted by Pontell and Geis (2007), Japanese social norms help reduce certain types of crime, but they may increase the likelihood of white-collar crime.

While the US, Britain, and Japan all have been part of large deregulatory movements, the primary difference between the American and British experiences and the Japanese experience has been the ability to recognize crises and re-regulate when scandals are discovered. The 1929 and 1987 stock market crashes were both met with regulations designed to prevent such disasters from re-occurring. Similar measures were taken after the Savings and Loan and Insider Trading scandals of the 1980s. The US also recently saw the largest corporate regulatory legislation in almost 70 years, when the Sarbanes Oxley reforms were passed in 2002. Similarly, Britain enacted the Banking Act of 1987 to eliminate some of the causes of the Johnson Matthey bank crisis, which forced that institution to go bankrupt (Geisst 1993). An inability to compensate for regulatory failures puts the Japanese economic system at significant risk for implosion, as evidenced by the 1997 Japanese banking collapse. The causes of the scandal were never fully addressed, which prolonged the resulting economic damage (Black 2004).

One cultural factor that may limit some of the potential for investment trust abuse is the Japanese investment strategy. While American investors are focused solely on financial objectives, Japanese investors establish relationships and give themselves monetary insurance through their investments (Ide 1998). While the influx of foreign investors seeking quick financial gain in a deregulated Japan may create opportunities for abuse, it seems unlikely that these abuses will come from domestic investors with relational, longterm objectives.

Another aspect that may aid Japan is the tendency to deregulate slowly. When the barrier between banks and securities firms was lifted in 1993, the Ministry of Finance maintained control over which firms received licenses to conduct both types of transactions. During the 1st year under the deregulated system, only five firms were approved to expand their business operations (Hamao and Hoshi 2000). This is in contrast to the American approach to deregulation in which any deregulatory measure is typically met with a flurry of activity, as organizations rush to take advantage of new opportunities. This was evident when the Glass-Steagall Act was removed, allowing for banks to conduct securities transactions. Banks had been anticipating the removal of the act for months before it happened, and some already had a plan in place to begin such transactions the 1st day they were allowed. The same occurred for discount brokerage firms, with several going into business on 1 May 1975 , the day that broker commissions were deregulated.

\section{Prospects for the Future}

Financial fraud may always occur on some scale, but the problem becomes more significant when it is endemic to a system. The issues salient in the American mutual fund scandal may easily be magnified in the Japanese case, given a similar competitive environment and less transparency and ability to recognize and address the problem. These factors, combined with the Japanese culture of greater adherence to social and business hierarchies, even when illegalities are involved, decreases the likelihood of early discovery of fraud. This helps create a crime-facilitative environment similar to the one that characterized the American mutual fund scandal. A reduced risk of detection in Japan could lead to more damage over a longer period of time than was seen in the United States. On the other hand, the lack of a 
large pool of funds from which to skim may keep abusive investors away from a vulnerable industry. If, and when, the Japanese mutual fund market begins to exhibit large growth; however, one would expect to see abuses similar to those found in the American mutual fund scandal.

Open Access This article is distributed under the terms of the Creative Commons Attribution Noncommercial License which permits any noncommercial use, distribution, and reproduction in any medium, provided the original author(s) and source are credited.

\section{Appendix 1}

Mutual fund transaction:

Investor $\square$ Broker-dealer $\square$ Order-ticket with time-stamp $\square$

Wired to clearing house or handled internally $\square$ Net orders sent to mutual fund

Step 1: The investor places an order with the broker-dealer to buy or sell the mutual fund.

Step 2: The broker-dealer records the order and an order ticket with a time-stamp is recorded.

Step 3: The order is then wired to a clearinghouse to be processed, or the order is processed within the brokerage firm's clearing division.

Step 4: The net orders are then sent along to the mutual fund company to be processed.

Late trading transaction:

The diagram is the same, but the steps are different.

Step 1: The investor places an order with the broker-dealer to buy or sell the mutual fund after the market has closed.

Step 2: The broker-dealer records the order and an order ticket with a fraudulent timestamp is recorded.

Step 3: If the news is in the investor's favor, the order is then wired to a clearinghouse to be processed, or the order is processed within the brokerage firm's clearing division. If the news is against the investor, then the order is not processed.

Step 4: The net orders are then sent along to the mutual fund company to be processed.

\section{References}

Black, W. K. (2004). The Dango tango: Why corruption blocks real reform in Japan. Business Ethics Quarterly, 14(4), 603-623.

Black, W. K. (2005). The best way to rob a bank is to own one. Austin: University of Texas Press.

Bogle, J. C. (2005). The battle for the soul of capitalism. New Haven: Yale University Press.

Damato, K., \& Burns, J. (2004). Quarterly mutual funds review; Cleaning up the fund industry; Regulators and Congress propose "unprecedented" changes, but critics say some moves would hurt investors. Wall Street Journal (Eastern edition). p. R1, April 5.

Elkind, P. (2004). The secrets of Eddie Stern. Fortune, 149(8), 106-128.

Geisst, C. R. (1993). A guide to financial institutions. London: Macmillan.

Geisst, C. R. (2000). 100 years of Wall Street. New York: McGraw-Hill. 
Geisst, C. R. (2004). Wall Street: From its beginnings to the fall of Enron. Oxford: Oxford University Press. Hall, M. J. B. (1998). Financial reform in Japan. Cheltenham: Elgar.

Hamao, Y., \& Hoshi, T. (2000). Bank-owned security subsidiaries in Japan: Evidence after the 1993 financial system reform. In M. Aoki \& G. R. Saxonhouse (Eds.), Finance, governance, and competitiveness in Japan (pp. 105-117). Oxford: Oxford University Press.

Hamilton, V. L., \& Sanders, J. (1996). Corporate crime through citizen's eyes: Stratification and responsibility in the United States, Russia, and Japan. Law \& Society Review, 30(3), 513-548.

Henriques, D. B. (2003). Fund compliance plans ignored trade timing. December 11. www.nytimes.com. Accessed 4 December 2006.

Henriques, D. B. (2004). Markets \& investing; A sense of history, a feeling of betrayal. January 2. www. nytimes.com. Accessed 23 September 2008. .

Ide, M. (1998). Japanese corporate finance and international competition. New York: St. Martin's.

Lutton, L. P. (2007). Letter to SEC: Make fund boards more independent. www.news.morningstar.com/ articlenet/article.aspx?id=188368\&_QSBPA=Y. Accessed 24 August 2007.

Lynch, M. (2006). Merrill Lynch. www.ir.ml.com/quick.cfm. Accessed 15 January 2008.

Malcolm, J. D. (2001). Financial globalisation and the opening of the Japanese economy. Richmond: Curzon.

McTamaney, R. (2003). New York's Martin Act: Expanding enforcement in an era of securities regulation. Washington Legal Foundation, 18(5), 1-4.

Media Center. (2003). State investigation reveals mutual fund fraud. Office of the Attorney General of the State of New York. www.ag.ny.gov/media_center/2003/sep/sep03a_03.html. Accessed 20 January 2007.

Needleman, M. L., \& Needleman, C. (1979). Organizational crime: Two models of criminogenesis. Sociological Quarterly, 20(4), 517-528.

NYSE. (2008). NYSE facts \& figures. www.nyxdata.com/nysedata/Default.aspx?tabid=115. Accessed 15 Jan 2008.

Pontell, H. N. (2004). White-collar crime or just risky business? The role of fraud in major financial debacles. Crime, Law and Social Change, 42(4-5), 309-324.

Pontell, H. N., \& Geis, G. (2007). Black mist and white collars: Economic crime in the U.S. and Japan. Asian Journal of. Criminology, 2(2), 111-126.

Potts, G. (1972). Understanding investments and mutual funds. New York: Arco.

Russell, R. (2007). An introduction to mutual funds worldwide. Chicester: Wiley.

Schwab, C. (2006). Annual report. www.aboutschwab.com/about/overview/index.html. Accessed 15 January 2008.

SEC. (2007). Mutual fund redemption fees. www.sec.gov/rules/final/ic-26782.pdf. Accessed 24 August 2007.

Solomon, D., \& Hechinger, J. (2004). Mutual funds' chiefs might lose strings. Wall Street Journal (Eastern edition). p. C1, June 22.

Sterngold, J. (1994). World markets; A new leaf for Japan's mutual funds? January 2 www.nytimes.com. Accessed 15 January 2008.

The Japan Times. (2004). Seibu Rail shirked board meetings, p. 1, December 19.

Thomas, L. Jr. (2006). Prudential to pay fine in trading. August 29. www.nytimes.com. Accessed 23 September 2006.

Toya, T. (2006). The political economy of the Japanese financial big bang. Oxford: Oxford University Press.

Wall Street Journal. (1999). Guide to understanding money \& investing. New York: Lightbulb.

Wheeler, S., \& Rothman, M. L. (1982). The organization as weapon in white-collar crime. Michigan Law Review, 80(7), 1403-1426.

Zitzewitz, E. (2003). Who cares about shareholders? Arbitrage-proofing mutual funds. Journal of Law, Economics, and Organization, 19(2), 245-280.

Zitzewitz, E. (2006). How widespread was late trading in funds? American Economic Review (Papers \& Proceedings), 284-289. 